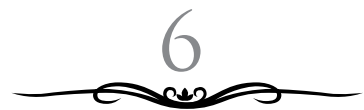

\title{
PERAN PUSTAKAWAN DALAM PENINGKATAN MUTU PENDIDIKAN PERGURUAN TINGGI MELALUI AKREDITASI PERPUSTAKAAN
}

\author{
Ulfah Rulli Hastuti \\ IAIN Purwokerto, Jawa Tengah, Indonesia \\ ulfahpwt@gmail.com
}

\begin{abstract}
This research use qualitative method which dominate with literature studies. Library has role in developing knowledge where need a good governance quality and it as standard in order to get a quality of intellectual generation. Traditional model does not fit in this information era. So in order that library accreditation is very essential to know how far the service in the righ track or nor as like human resource management, activities and the collection. The role of librarian in the accreditation process of library has been begin from planning, team formation, learning accreditation borang, prepare supporting data, valuing borang up to visitation of assecor. Whatever the result of accreditation, the most important is making the result of accreditation as motivation to increase education quality with of library.
\end{abstract}

Keywords: Quality Education, Library Acreditation

\begin{abstract}
Abstrak
Perpustakaan yang berperan dalam pengembangan keilmuan memerlukan sistem pengelolaan yang bermutu dan sesuai standar yang ditetapkan agar dapat melahirkan generasi intelektual yang berkualitas. Pengelolaan perpustakaan secara tradisional tidak sesuai lagi dengan era informasi saat ini.
\end{abstract}


Maka dari itu akreditasi perpustakaan sangat penting untuk dilakukan untuk mengetahui sejauh mana kualitas pengelolaan yang dilakukan baik dari segi sumber daya manusianya, kegiatan maupun koleksi yang dimiliki. Peran pustakawan dalam proses akreditasi perpustakaan dimulai dari perencanaan akreditasi, pembentukan tim, mempelajari boring akreditasi, menyiapkan data pendukung, penilaian borang sampai visitasi tim asesor. Apapun hasil dari akreditasi, hal terpenting adalah menjadikan hasil akreditasi sebagai motivasi untuk peningkatan mutu pendidikan melalui perpustakaan.

Kata Kunci: Mutu Pendidikan, Akreditasi Perpustakaan

\section{A. Pendahuluan}

Dalam pendidikan Perguruan tinggi di Indonesia terkandung tiga nilai dasar yang wajib dilaksanakan oleh setiap perguruan tinggi yang dikenal dengan Tridharma perguruan tinggi. Tiga dimensi itu terdiri dari pendidikan, penelitian dan pengabdian. Dengan melaksanakan tiga fungsi yaitu pendidikan, penelitian dan pengabdian kepada masyarakat perguruan tinggi menjadi tumpuan harapan masyarakat. Harapan untuk menjadi agen perubahan ( agent of social change) agar lulusan dari perguruan tinggi nantinya dapat memberi pencerahan kepada masyarakat dalam rangka meningkatkan taraf hidup dan kesejahteraan masyarakat dengan kualifikasi yang di peroleh selama proses pembelajaran.

Pada era globalisasi saat ini masyarakat sangat membutuhkan pendidikan yang berkualitas. Hal ini sangat beralasan karena luasnya sektor lapangan kerja seperti sektor perdagangan, pertanian, jasa, industri, keuangan pertambangan dan lain sebagainya membutuhkan tenaga kerja dan semakin banyaknya persaingan lulusan perguruan tinggi lainnya. Untuk dapat melaksanakan Tri Dharma secara berkesinambungan perguruan tinggi harus melibatkan seluruh unsur penunjang yang ada di lingkungan akademik. Salah satu unsur penunjang adalah sarana sumber belajar berupa perpustakaan. Keberadaan 
perpustakaandalamsebuahperguruantinggisangatpentingadanya. Perpustakaan sebagai pusat informasi yang mendokumentasikan pengetahuan dalam berbagai media untuk memenuhi kebutuhan keilmuan para pelanggannya. Sebagaimana disebutkan dalam Peraturan Pemerintah Nomor 4 Tahun 2014 Bagian keempat tentang tata kelola perguruan tinggi pasal 28 butir (d) menyatakan bahwa unsure penunjang yang perlu ada pada organisasi PTN dan PTS adalah penunjang akademik atau sumber belajar. ${ }^{1}$ Sebagai unit yang memegang peranan penting, perpustakaan membutuhkan tata kelola dan manajemen yang serius agar dapat membantu melaksanakan tridharma perguruan tinggi. Bagaimana peran pustakawan sebagai pengelola perpustakaan perguruan tinggi dalam mewujudkan mutu perpustakaan untuk memenuhi kebutuhan pelanggannya?

\section{B. Pembahasan}

\section{Perguruan Tinggi dan Penjaminan Mutu Pendidikan}

Dalam pasal 19 ayat (1) Undang-Undang No. 20 tahun 2003 tentang Sistem Pendidikan Nasional disebutkan bahwa pendidikan tinggi merupakan jenjang pendidikan setelah pendidikan menengah yang mencakup program pendidikan diploma, sarjana, magister, spesialis dan doctor yang diselenggarkan oleh perguruan tinggi. Unsur-unsur pengelola dalam perguruan tinggi terdiri dari pimpinan, dosen, tenaga penunjang akademik dan pegawai administrasi. Siapa yang menjadi pelanggan dalam perguruan tinggi? Pelanggan perguruan tinggi menurut Daulat B. Tampubolon ada tiga yaitu pelanggan primer (mahasiswa), pelanggan sekunder (pengelola, pemerintahan, orang tua, masyarakat, organisasi/ lembaga sponsor, pelanggan tersier ( dunia kerja, dan lain-lain ). ${ }^{2}$

${ }^{1}$ Peraturan Pemerintah Nomor 4 Tahun 2014 Tentang Tata Kelola Perguruan Tinggi.hlm.12

${ }^{2}$ Daulat P. Tampubolon.Perguruan Tinggi Bermutu. ( Jakarta: Gramedi aPustaka Utama, 2001 ) hal. 155 
Perguruan tinggi sebagai jasa industry pendidikan dituntut untuk menghasilkan lulusan yang bermutu sesuai dengan yang dikehendaki steakholder (mahasiswa, orang tua, masyarakat, pemerintah, dunia kerja). Untuk dapat menghasilkan lulusan berkualitas perguruan tinggi harus dapat menyelenggarakan pendidikan yang bermutu sehingga kualifikasi lulusan nantinya siap menghadapai persaingan dengan lulusan dari perguruan tinggi lainnya.

Perguruan tinggi dalam menjalankan visi dan misi berorientasi pada ilmu pengetahuan sehingga memerlukan manejemen yang berkaitan erat dengan pemanfaatan dan pengembangan ilmu pengetahuan. Dalam pengembangan manajemen pengetahuan ada beberapa proses yang diusulkan oleh Galagan dalam Syahrial Abbas yaitu :

a. Mencipatakan pengetahuan baru

b. Mengakses pengetahuan dari sumber eksternal

c. Menyimpan pengetahuan dalam dokumen, data base, perangkat lunak dan sebagainya.

d. Mewujudkan dan menggunakan pengetahuan dalam proses, produk dan jasa

e. Mentransfer pengetahuan yang dimiliki di lingkungan peruasahaan

f. Menggunakan pengetahuan dalam proses pengambilan keputusan

g. Mempelancar pengetahuan melalui budaya dan insentif

h. Mengukur nilai asset pengetahuan dan dampaknya pada manajemen pengetahuan. ${ }^{3}$

Selain memerlukan pengembangan manajemen, untuk mencapai tujuan pendidikan dan menjaga eksistensi peguruan tinggi perlu adanya penjaminan mutu atau pemenuhan standar mutu pengelolaan perguruan tinggi.

Definisi penjaminan mutu berdasarkan pedoman penjaminan mutu Perguruan Tinggi - Dikti 2003 yaitu penjaminan

${ }^{3}$ Syahrial Abbas.Manajemen Perguruan Tinggi .( Jakarta : Prenada Media, 2009 ) hlm. 104 
mutu pendidikan tinggi di perguruan tinggi adalah proses penetapan dan pemenuhan standar mutu pengelolaan pendidikan tinggi secara konsisten dan berkelanjutan, sehingga stakeholder: mahasiswa, orangtua, dunia kerja, pemerintah, dosen, tenaga penunjang, serta pihak lain yang berkepentingan memperoleh kepuasan. Secara internal penjaminan mutu di perguruan tinggi difasilitasi oleh pimpinan perguruan tinggi yang bersangkutan sedangkan secara eksternal penjaminan mutu perguruan tinggi melibatkan Badan Akreditasi Nasional Perguruan Tinggi (BANPT) atau lembaga lain yang berkompeten.

Tujuan penjaminan mutu pendidikan tinggi adalah untuk menjamin pemenuhan Standar Pendidikan Tinggi secara sistematik dan berkelanjutan, sehingga tumbuh dan berkembang budaya mutu. ${ }^{4}$ Beberapa strategi penjaminan mutu yang dapat dilakukan oleh perguruan tinggi seperti yang dikemukakan oleh Buchori Alma adalah :

a. Mengemban sistem penjaminan mutu dan perangkat implementasinya

b. Membangun atau meningkatkan komitmen pimpinan dan seluruh unit kerja untuk melaksanakan penjaminan mutu setiap kegiatan yang diselenggarakan sesuai dengan system penjaminan mutu yang ditetapkan dan perangkat implementasinya

c. Menetapkan sasaran atau standar mutu perguruan tinggi dan unit kerja di lingkungan perguruan tinggi yang bersangkutan untuk setiap periode mutu

d. Mengidentifikasi suatu kegiatan untuk setiap butir mutu pada setiap tahap dalam proses bisnis perguruan tinggi, serta menetapkan kegiatan yang mutunya dijaminkan. ${ }^{5}$

Komponen yang menentukan mutu perguruan tinggi yaitu dosen, tenaga penunjang, mahasiswa, sarana parasarana,

\footnotetext{
${ }^{4}$ Permendikbud Nomor 50 Tahun 2014.hlm.3

${ }^{5}$ Buchari Alma ( editor ).Manajemen corporate \& strategi pemasaran jasa pendididkan : focus pada mutu dan layanan prima. ( Bandung : Alfabeta, 2009 ) hlm. 77
} 
lingkungan dan kepemimpinan. Pelaksanaan penjaminan mutu di perguruan tinggi dapat dilakukan dengan menerapkan nilai-nilai TQM. Pedoman penjaminan mutu yang dikeluarkan oleh Dirjen Dikti Depdiknas-2003 secara tegas menyatakan bahwa pemilihan dan penetapan standar mutu dilakukan dalam sejumlah aspek yang disebut butir-butir mutu yang meliputi : kurikulum program studi, sumber daya manusia, (dosen dan tenaga penunjang), mahasiswa, proses pembelajaran, sarana prasarana, suasana akademik, keuangan, penelitian dan publikasi, pengabdian kepada masyarakat, tata pamong, manajemen lembaga, system informasi, serta kerjasama dalam dan luar negeri. Akreditasi merupakan suatu hal yang sangat penting bagi dunia pendidikan. Menurut peraturan pemerintah No. 19 tahun 2005 tentang Standar Nasional Pendidikan BAB I pasal (1) point 21 akreditasi adalah kegiatan penilaian kelayakan program dan/atau satuan pendidikan berdasarkan criteria yang telah ditetapkan. ${ }^{6}$

Dalam sejumlah aspek penjaminan mutu salah satu isi dari butir-butir mutu adalah sarana dan prasarana dalam pendidikan. Sarana prasarana yang akan dibahas dalam hal ini adalah berupa perpustakaan. Perpustakaan sebagai sumber belajar bagi masyarakat pembelajar memerlukan pengelolaan yang serius agar dapat menjalankan fungsinya dengan optimal. Pengelolaan perpustakaan yang dikelola sesuai dengan standar perpustakaan sangat diharapkan dapat memberikan layanan yang semaksimal mungkin kepada pengguna dalam memenuhi kebutuhan informasinya. Untuk menjamin adanya layanan yang baik maka pihak pemerintah melalui Perpustakaan Nasional melakukan penilaian atau akreditasi terhadap perpustakaan. Dengan adanya penilaian atau akreditasi perpustakaan ini perpustakaan perguruan tinggi diharapkan dapat dijamin standar kualitas yang dibutuhkan oleh perpustakaan Perguruan Tinggi. Proses akreditasi perpustakaan perguruan tinggi sebagai kebutuhan yang menyangkut kepentingan banyak pihak dilingkungan Perguruan

${ }^{6}$ Peraturan Pemerintah Nomor 19 tahun 2005 tentang Standar Nasional Pendidikan. Hlm. 3 
Tinggi . Perhatian, dukungan dan persiapan yang sungguhsungguh dari segenap lingkungan sivitas akademika khususnya pihak pustakawan beserta segenap pegawai yang bertugas di perpustakaan sangat diperlukan dalam proses akreditasi nantinya.

\section{Akreditasi Perpustakaan Perguruan Tinggi dan Tujuannya}

Pengertian akreditasi sesuai dengan peraturan pemerintah Nomor 24 Tahun 2014 BAB I Pasal 1 butir (3) adalah serangkaian kegiatan proses pengakuan formal oleh lembaga akreditasi yang menyatakan bahwa suatu lembaga telah memenuhi persyaratan untuk melakukan kegiatan sertifikasi tertentu. ${ }^{7}$ Perpustakaan adalah bagian dari lembaga pendidikan yang sangat penting keberadaannya dalam membantu proses pembelajaran dan penyebaran ilmu pengetahuan. Sebaik apa pun pengalaman dan pengetahuan yang dimiliki sesorang hanya akan berhenti dalam benak pikiran jika tidak diabadikan dalam suatu media dan tidak disebar luaskan. Pengetahuan yang dihasilkan oleh pemikiran manusia akan lebih berguna dan mempunyai nilai manfaat apabila di simpan dan sebarluaskan agar masyarakat dapat mengambil manfaatnya dan dapat mengaplikasikan untuk meningkatkan taraf kehidupan yang lebih baik. Salah satu tempat yang meghimpun dan menyebarkan ilmu pengetahuan adalah perpustakaan yang dapat dimanfaatkan oleh pengguna yang mengakses dan memanfaatkan koleksinya dengan membaca.

Perpustakaan Perguruan Tinggi adalah perpustakaan yang diselenggarakan oleh lembaga Pergururan Tinggi. Dalam melaksanakan Tri Dharma Perguruan Tinggi perpustakaan bekerjasama dengan unit lain seperti pusat penelitian, pusat bahasa, pusat penjaminan mutu dan unit lain yang ada di lingkungan perguruan tinggi. Sebagai unit pelaksana teknit (UPT) yang menunjang pelaksanaan Tri Dharma Perguruan Tinggi,

\footnotetext{
${ }^{7}$ Peraturan Pemerintah Nomor 24 Tahun 2014.hlm.2
} 
perpustakaan perguruan tinggi memiliki tujuan seperti yang dikemukakan oleh Syihabudin Qalyubi yaitu :

a. Memenuhi keperluan informasi pengajar dan mahasiswanya.

b. Menyediakan bahan pustaka rujukan pada semua tingkat akademis.

c. Menyediakan ruangan untuk pemakainya.

d. Menyediakan jasa penjaman serta menyediakan jasa informasi aktif bagi pemakai. ${ }^{8}$

e. Perpustakaan Perguruan Tinggi berbeda dengan perpustakaan sekolah maupun perpustakaan umum. Dari segi pengguna dan jenis koleksinya perpustakaan perguruan tinggi lebih kompleks dan bervariasi.

Dalam perpustakaan perguruan tinggi pemakainya tidak hanya mahasiswa dan dosen, akan tetapi seluruh civitas akademika yaitu pegawai, dan para peneliti. Kegiatan dan tujuan utama dalam setiap perpustakaan adalah memberikan pelayanan informasi kepada pengguna. Untuk perpustakaan perguruan tinggi kualitas atau mutu dalam sebuah lembaga pendidikan seperti perguruan tinggi menjadi suatu kebutuhan atau hal yang sangat penting karena hal ini merupakan tuntutan masyarakat. Tuntutan kualitas pada perguruan tinggi baik di lembaga perguruan tinggi Islam maupun perguruan tinggi umum, baik negeri maupun swasta saling terkait dan sejalan dengan tuntutan pasar bebas di era reformasi yang mengarah pada pasar bebas. Demikian juga dengan unit perpustakaan yang dituntut oleh masyarakat penggunanya untuk dapat menunjukkan dan memberikan layanan prima dan berkualitas.

Dalam konteks jasa pendidikan tinggi, perpustakaan dapat dianggap sebagai bukti fisik sebagai sarana pendukung proses pembelajaran di perguruan tinggi. Hal ini mengacu pada definisi perpustakaan dalam Undang-Undang No.43 Tahun 2007 BAB I Pasal 1 butir (1) tentang Perpustakaan. Sebagai institusi

${ }^{8}$ Syihabuddin Qalyubi, dkk. Dasar-dasar ilmu perpustakaan. ( Yogyakarta: Jurusan Ilmu Perpustakaan dan Ilnformasi, 2009 ) hlm. 11 
yang mengelola karya tulis dan karya rekam hasil penelitian perpustakaan menjadi sumber belajar dan sarana pendukung penting dalam pengembangan keilmuan di perguruan tinggi, perpustakaan memerlukan pengelolaan dan penataan yang baik. Sebagai jantungnya sebuah perguruan tinggi yang berarti juga sebagai nadi bagi perguruan tinggi perpustakaan harus mampu memenuhi kebutuhan steakholder utamanya yaitu mahasiswa dan dosen untuk pengembangan keilmuan. Dalam memenuhi kebutuhan steakholder dari segi koleksi, perpustakaan harus dapat menyediakan referensi yang sesuai dengan kebutuhan steakholder dan bukan sebaliknya hanya menyediakan refensi sesuai dana proyek yang diberikan setiap tahun tanpa memperhatikan nilai guna yang menunjukkan kualitas koleksi. Hal inilah yang mendorong untuk dilakukan akreditasi atau penilaian terhadap kualitas manajemen yang dijalankan.

Sebagai unit penunjang Tri Dharma perguruan tinggi perpustakaan harus berbenah diri dan menyiapkan segala keperluan untuk pelaksanakan akreditasi. Akreditasi merupakan kondisi di dalamnya bila sebuah lembaga terakreditasi maka hal itu memberi kepercayaan kepada public bahwa sebuah perpustakaan beserta koleksi, jasa, sumber daya manusia, dan fasilitas yang lain memenuhi kkomitmen pada mutu perpustakaan. Akreditasi memberikan assessment dan penguatan mutu atau pendayagunaan yang efektifakan sumber dayaguna mencapai tujuan perpustakaan. Tujuan akreditasi secara umum menurut pakar perpustakaan Sulistyo Basuki adalah :

a. Memperbaiki lembaga yang diakreditasi jika yang diakreditasi adalah perguruan tinggi maka akreditasi bertujuan memperbaiki perguruan tinggi. Bila yang diakreditasi adalah perpustakaan maka hasil akreditasi menunjukkan apakah hasilny masih kurang memenuhi standar, Bila masih kurang memenuhi standar maka perpustakaan perguruan tinggi diberikan kesempatan untuk memperbaiki.

b. Meningkatkan standar profesi. Di Indonesia organisasi 
profesi seperti Ikatan Pustakawan Indonesia belum melakukan akreditasi lembaga pendidikan pustakawan karena organisasi itu sendiri masih belum mapan menyangkut perakreditasian.

c. Memberikan informasi bagi umum. Masyarakat dapat mengetahui mana perguruan tinggi yang memperoleh akreditasi tinggi atau tidak dengan dilakukannya akreditasi.

d. Memudahkan perpindahan dari sebuah perguruan tinggi ke perguruan tinggi lain karena ada satuan kredit semester kredit yang dapat ditransfer. Bila dua perguruan tinggi dengan program studi yang sama sudah terakreditasi dengan hasil memuaskan, maka transfer satuan kredit antara satu program studi dengan program studi sejenis dapat dilakukan tanpa perlu ada ketentuan baru. ${ }^{9}$

\section{Pustakawan dan Akreditasi Perpustakaan}

Pustakawan merupakan sebuah profesi yang erat kaitannya dengan dunia pendidikan dan berpayung hukum serta diakui keberadaannya di masyarakat. Pengertian pustakawan menurut Undang-Undang No 43 tahun 2007 tentang Perpustakaan dalam pasal 29 ayat 1 bahwa tenaga perpustakaan terdiri atas pustakawan dan tenaga teknis perpustakaan. ${ }^{10}$ Pustakawan adalah pegawai negeri sipil yang diberi tugas, wewenang, dan hak secara penuh oleh pejabat yang berwenang untuk melakukan kegiatan kepustakawanan pada unit-unit perpustakaan, dokumentasi dan informasi (perpusdokinfo) di instansi pemerintah dan /atau unit tertentu lainnya. ${ }^{11}$

${ }^{9}$ Sulistyo Basuki. "Akreditasi Perpustakaan Perguruan Tinggi”. http:// sulistyobasuki.wordpress.com/2013/10/27 akreditasi-perpustakaan-perguruan tinggi/

${ }^{10}$ Undang-undang No.43 Tahun 2007 tentang Perpustakaan

${ }^{11}$ Peraturan Kepala Perpustakaan Nasional Republik Indonesia Nomor 2 Tahun 2008 
Menurut Peraturan Kepala perpustakaan Nasional Republik Indonesia Nomor 11 tahun 2015 pada Bab II butir ke 28 disebutkan bahwa pustakawan adalah Pegawai Negeri Sipil (PNS) yang diberi tugas, tanggung jawab, wewenang, dan hak untuk melaksanakan kegiatan kepustakawanan. ${ }^{12}$ Jabatan fungsional pustakawan pertama kali diatur dengan Keputusan Menteri Negara Pendayagunaan Aparatur Negara Nomor 18/ MENPAN/1988 tentang angka kredit bagi jabatan Pustakawan, dan kemudian direvisi terakhir dengan keputusan MENPAN Nomor 132/KEP/M.PAN/12/2002 tentang Jabatan Fungsional Pustakawan dan angka kreditnya. Mengenai kegiatan pustakawan banyak sekali jenis kegiatan yang harus dilakukan baik di dalam perpustakaan maupun kegiatan kepustakawanan di luar perpustakaan. Dalam melaksanakan kegiatan kepustakawanan pustakawan hendaknya mengetahui dan memahami jenis-jenis kegiatan yang menjadi ladang karya dalam rangka meningkatkan profesionalismenya sebagai pustakawan.

Kegiatan pustakawan yang tercantum dalam Keputusan Menpan Nomor 132/KEP/M.PAN/12/2002 dan Keputusan Bersama Kepala Perpustakaan Nasional RI dan Kepala Badan Kepegawaian Negara Nomor 23 dan 21 tahun 2003 tentang petunjuk pelaksanaan jabatan fungsional dan angka kreditnya diperbaharui dengan Permenpan RB nomor 9 tahun 2014. ${ }^{13}$ Kegiatan yang dilakukan pustakawan terdiri dari dua unsur yaitu unsur utama dan unsur penunjang. Beberapa kegiatan unsur utama kegiatan pustakawan berdasarkan KEPMENPAN NOMOR 132/2002 terdiri dari unsure kegiatan : Pengorganisasian dan pendayagunaan koleksi bahan pustaka/sumber informasi, Pemasyarakatan perpustakaan, dokumentasi dan informasi, serta pengembangan profesi. Beberapa tahun kemudian unsur utama kegiatan kepustakawanan mengalami perubahan sesuai dengan

${ }^{12}$ Peraturan Kepala Perpustakaan Naional Republik Indonesia Nomor 11 tahun 2015 Bab II butir 28

${ }^{13}$ Peraturan Kepala Perpustakaan Nasional Republik Indonesia Nomor 2 Tahun 2008.hlm. 1 
PERMENPAN DAN REFORMASI BIROKRASI RI NOMOR 9 TAHUN 2014 sehingga unsur utama kegiatan kepustakawanan sesuai peraturan terbaru terdiri dari : pengolahan perpustakaan, pelayanan perpustakaan, pengembangan sistem kepustakawanan dan Pengembangan profesi.

Kegiatan unsur penunjang kegiatan kepustakawanan berdasarkan KEPMENPAN NOMOR 132/2012 terdiri dari mengajar, melatih, membimbing mahasiswa, memberikan konsultasi teknis, mengikuti seminar, lokakarya, dan pertemuan sejenis, menjadi anggota organisasi profesi kepustakawanan, mengikuti lomba/menjadi dewan juri lomba kepustakawanan, mendapat penghargaan/tanda jasa, memperoleh gelar kesarjanaan lainnya, menyunting risalah pertemuan, dan menjadi anggota tim penilai. Sesuai dengan PERMENPAN REFORMASI BIROKRASI NOMOR 9/2014 unsur penunjang dalam kegiatan kepustakawanan mengalami perubahan sehingga unsur penunjang kegiatan kepustakawanan terdiri dari : pengajar/pelatih pada diklat fungsional/teknis, peran serta dalam seminar/lokakarya/ konferensi, keangotaan dalam tim penilai, dan perolehan penghargaan.

Sebagai petunjuk dan pedoman pustakawan dalam melakukan kegiatan kepustakawanan dalam rangka mengembangkan profesinya hendaknya kegiatan yang dilakukan harus disesuaikan dengan peraturan jabatan fungsional yang tercantum dalam peraturanyangtelahdisahkan. Beberapaperaturan yang wajib diketahui dan dipahami oleh pustakawan seperti yang dikutip oleh Tri Hardinintyas adalah sebagai berikut:

a. Keputusan Menpan Nomor 132/KEP/M.PAN/12/2002 dan Keputusan Bersama Kepala Perpustakaan Nasional RI dan Kepala Kepegawaian Negara Nomor 23 dan 21 tahun 2003 tentang petunjuk pelaksanaan jabatan fungsional dan angka kreditnya, dan diperbaharui dengan Permenpan nomor 9 tahun 2014

b. Peraturan Kepala Perpustakaan Nasional RI Nomor 2 tahun 2008 tentang Petunjuk teknis jabatan fungsional 
pustakawan dan angka kreditnya

c. Undang-undang Nomor 43 tahun 2007 tentang perpustakaan yang disempurnakan dengan Peraturan Pemerintah nomor 24 tahun 2014. ${ }^{14}$

Peraturan yang telah disahkan menjadi dasar dan panduan pustakawan dalam menjalankan kegiatan kepustakawanannya dalam jenjang karier merupakan kitab pedoman yang sangat penting dan wajib untuk diketahui, dipahami karena Undangundang dan peraturan tersebut merupakan payung hukum dan petunjuk teknis jabatan fungsional pustakawan. Jabatan fungsional pustakawan yang telah mendapat mengakuan dan legalitas hukum semakain menguatkan dan memotivasi pustakawan untuk lebih berkarya dan mengembangkan potensi diri dalam berkarier dalam bidang kepustakawanan. Jabatan Fungsional pustakawan adalah jabatan yang mempunyai ruang lingkup, tugas, tanggung jawab, wewenang, dan hak untuk melaksanakan kegiatan kepustakawanan.

Berikut ini penulis uraikan dalam tabel mengenai jenjang jabatan, pangkat (golongan/ruang) dan angka kredit pustakawan sesuai Peraturan Kepala Perpustakaan Nasional Nomor 11 Tahun 2015. Kredit.

Tabel 1. Jenjang Jabatan, Pangkat ( Golongan/Ruang ) Dan Angka

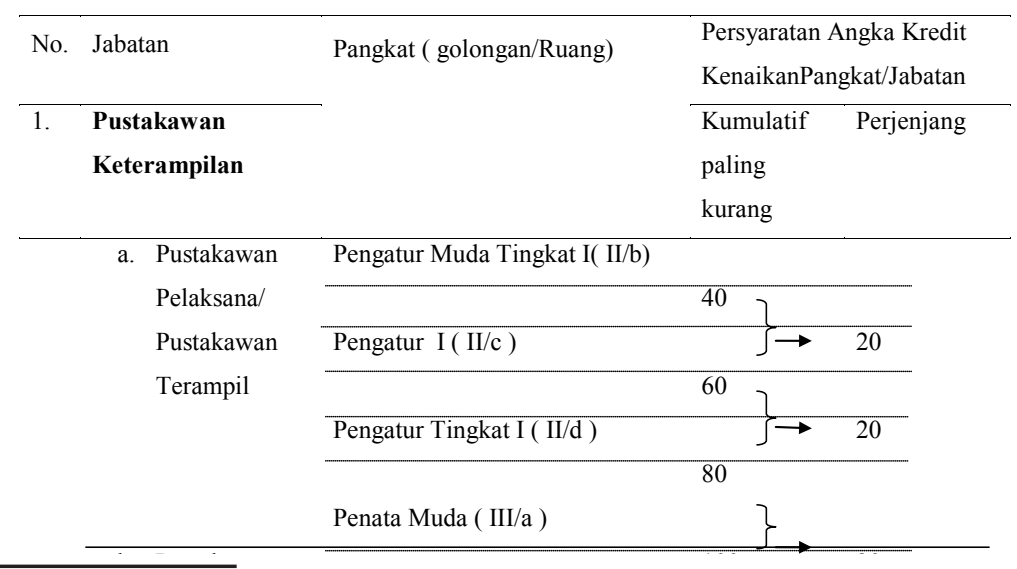

${ }^{14}$ Tri Hardiningtyas, Pustakawan \& angka kreditnya. ( Yogyakarta: Lembaga Ladang Kata, 2015 ), hlm. 15 


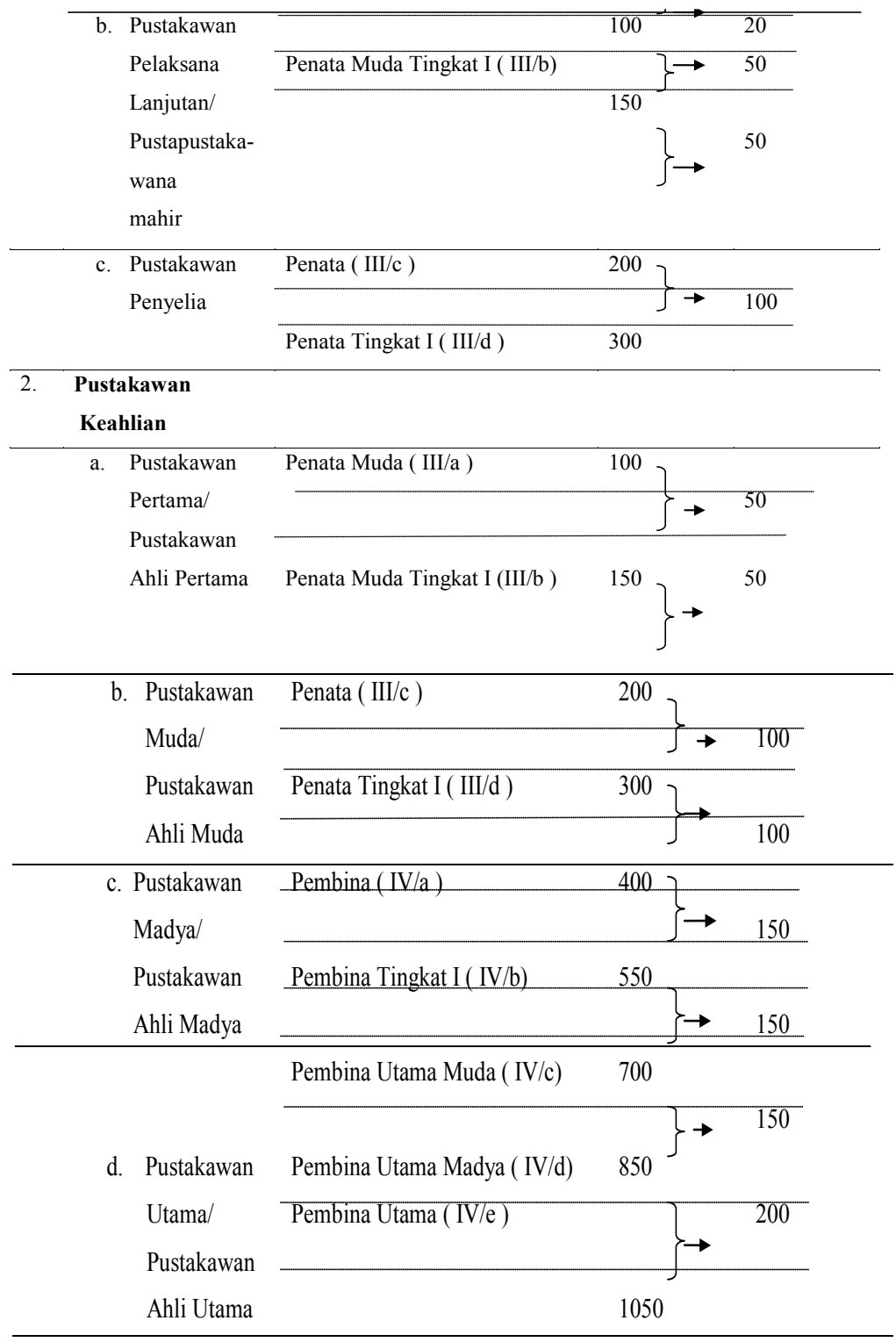

Sumber : Peraturan Kepala Perpustakaan Nasional Republik Indonesia Nomor 11 Tahun 2015, ( $2015: 8$ ) 


\section{Manajemen Mutu di Perpustakaan}

Pengertian mutu menurut Kamus Besar Bahasa Indonesia adalah ukuran baik buruk suatu benda; kadar, taraf atau derajat (kepandaian, kecerdasan, dsb). Bermutu berarti baik (tinggi); berbobot. ${ }^{15}$ Dalam ilmu ekonomi mutu dapat dijadikan sebagai penilaian terhadap suatu produk. Semakin bermutu produk yang dihasilkan akan mempengaruhi perilaku konsumen yang pada akhirnya akan berpengaruh pada tingkat produksi dan volume penjualan. Mutu adalah sesuatu yang harus diciptakan dan sangat penting untuk dipertahankan. Menjaga mutu sama artinya menjaga atau mempertahankan pelanggan. Dalam dunia bisnis kita mengenal pelanggan sebagai raja, sedangkan dalam dunia pendidikan khususnya di perpustakaan pemustaka selanjutnya disebut sebagai pelanggan dapat diistilahkan sebagai pemegang "kekuasaan "selaku pemakai/pengguna informasi yang mempunyai kebebasan untuk mengakses informasi dan berhak mendapat berbagai layanan jasa yang tersedia di perpustakaan.

Definisi mutu menurut beberapa ahli hampir menmpunyai kesamaan kendati tidak ada pengertian mutu yang dapat diterima secara umum. Dari beberapa pendapat, pengertian mutu memiliki kesamaan sebagai berikut :

a. Mutu meliputi usaha memenuhi atau melebihi harapan pelanggan (dalam hal ini adalah steakholder);

b. Mutu mencakup produk, jasa, manusia, proses, dan lingkungan;

c. Mutu merupakan kondisi yang selalu berubah (sesuatu yang saat ini dianggap bermutu kemungkinan akan dianggap kurang bermutu diwaktu atau paa masa yang akan datang). ${ }^{16}$

15 Kamus Besar Bahasa Indonesia. ( Jakarta : Balai Pustaka, 2010),hlm. 768

${ }^{16}$ Rinda Hedwig \&Gerardus Polla, Model Sistem Penjaminan Mutu \& Proses Penerapannya di Perguruan Tinggi. ( ogyakarta : Graha Ilmu, 2006 ), hlm. 2 
Ukuran mutu dalam perpustakaan lebih menunjukkan atau cenderung pada tingkat pelayanannya, namun demikian bukan berarti hanya pelayanan saja yang dituntut untuk menjaga kualitas mutunya. Ketersediaan koleksi, sarana pendukung penelusuran informsi juga harus bermutu. Bagaimana perpustakaan dapat mengukur mutu agar sesuai dengan atau memenuhi syarat standar yang ditetapkan. Pengukuran mutu didasarkan pada alat ukur yang ditetapkan atau standar yang dipakai. Beberapa contoh standar seperti yang dikutip oleh Abdul Rahman Saleh adalah sebagai berikut :

a. Standar mengenai air minum dalam kemasan (SNI 013553-2006)

b. Standar mengenai system manajemen mutu (SNI ISO 9001:2008)

c. Standar Perpustakaan Perguruan Tinggi (SNI 7330:2009) dan msh banyak standar lain yang ditetapkan. ${ }^{17}$

Fungsi dari penetapan standar adalah untuk memastikan bahwa produk dan layanan yang diberika perpustakaan berkualitas baik, bermutu dan meyakinkan pemustaka sebagai pelanggan. Dengan adanya standar yang ditetapkan maka pengguna atau pelanggan akan lebih mudah dalam meyakinkan dan memastikan untuk memakai atau mengggunakan jasa yang ditawarkan di perpustakaan. Perpustakaan sebagai bagian dari institusi pendidikan perlu mengembangan sistem pengelolaannya agar dapat membuktikan kepada steakholder (mahasiswa, masyarakat, pemerintah ) bahwa perpustakaan dapat memberikan produk sesuai dengan apa yang dibutuhkan oleh pengguna dengan kualitas yang bermutu. Dalam upaya pencapaian layanan yang bermutu perpustakaan harus dapat memahami, merespon dengan simpatik terhadap kebutuhan pengguna perpustakaan. Pengelolaan perpustakaan dalam meningkatkan mutu pelayanan yang standar dibutuhkan kerja keras dan usaha yang optimal dengan menerapkan system manajemen mutu di perpustakaan. Mengenai

17 Abdul Rahman Saleh, 'Penerapan Sistem Manajemen Mutu di Perpustakaan”, Media Pustakawan, Vol.22 No. 2 ( 2015 ), hlm. 12 
standar mutu suatu barang maupun jasa berikut ini gambaran untuk membedakan antara standar produk dan jasa dengan standar pelanggan ${ }^{18}$. Berikut ini adalah gambar yang membedakan antara standar produk dan jasa dengan standar pelanggan.

Gambar 1. Standar-standar mutu

\begin{tabular}{c}
\hline STANDAR PRODUK DAN JASA \\
Kesesuaian dengan spesifikasi \\
Kesesuaian dengan Tujuan dan Manfaat \\
Tanpa Cacat ( zero Defect ) \\
Selalu baik sejak awal \\
STANDAR PELANGGAN \\
Kepuasan Pelangga \\
Memenuhi Kebutuhan Pelanggan \\
Menyenangkan Pelangga
\end{tabular}

Sumber: Edwar Sallis.Manajemen Mutu Terpadu.

Dalam rangka usaha pengembangan budaya mutunya, perpustakaan dapat menerapkan system manajemen dengan pendekatan konsep TQM (Total Quality Manajement) atau yang dikenal dengan konsep PDCA (Plan, Do, Chek, Action). Salah satu bentuk implementasi konsep TQM dalam system manajemen adalah Quality Manajement System ISO 9000.. Internasional Standar Organization (ISO) merupakan system manajemen yang mensyaratkan bahwa manajemen organisasi harus berdasarkan standar (kausul) sepeti yang disyaratkan oleh

${ }^{18}$ Edward Sallis. Manajemen Mutu Terpadu Pendidikan. (Jogjakarta : IRCisSoD. 2011), hlm.57 
ISO ini. ${ }^{19}$ Konsep TQM ini biasa diterapkan di perusahaan baik perusahaan dalam negeri maupun luar negeri. Keberhasilan dalam penerapan manajemen mutu sangat dipengaruhi oleh komitmen eksekutif organisasi dalam hal ini adalah pimpinan perpustakaan. Dalam menghadapi persaingan dalam dunia informasi khususnya perpustakaan harus berusaha keras untuk dapat mengimplementasikan system manajemen mutu. Sistem Manajemen mutu menurut (SMM) ISO 9000:2008 merupakan system yang menjadi bagian dari Manajemen Mutu Terpadu (total quality management).

Perpustakaan yang akan menerapkan sistem manajemen mutu 9001 harus memahami prinsip-prinsip yang terdapat dalam SNI ISO 9001 yaitu (BSN,2010) dan (BSN,2013)

a. Fokus pada pelanggan

Pelanggan dalam dunia pendidikan merupakan wasit terhadap mutu dan lembaga itu sendiri, yang dalam hal ini pelanggan adalah pemustaka. Menurut Peter seorang ahli manajemen bahwa mutu yang diharapkan oleh pelanggan jauh lebih penting dibandingkan harga dalam menentukan permintaan barang dan jasa. Dalam konsep perpustakaan pelanggan yaitu pemustaka bukanlah konsep yang baru. Hal ini karena konsep pelanggan telah lama diterapkan dalam lima hukum perpustakaan yang dipelopori oleh Ranganatan. Menurut Tom Peters dalam ThrivinfOn Chaos seperti yang dikutip oleh Edward Sallis yang membicarakan bahwa peran penting pelanggan dalam menentukan mutu dengan menekankan bahwa sebuah mutu yang dirasa (perceived quality) dari sebuah produk bisnis atau jasa adalah faktor utama yang mempengaruhi kesuksesan sebuah organisasi dalam menjalankan kegiatannya.

b. Kepemimpinan

Dalam pengelolaan suatu organisasi termasuk

19 Bambang Sumardjoko, Membangun Budaya Pendidikan Mutu Perguruan Tinggi. ( Yogyakarta : Pustaka Pelajar, 2010 ), hlm. 68 
perpustakaan, peran serta kepemimpinan dalam membangun kesatuan visi dan misi yang jelas untuk mencapai tujuan demi masa depan perpustakaan.Gaya kepemimpinan yang mementingkan komunikasi visi dan nilai-nilai lembaga kepada pihak lain serta berbaur dengan para staf dan pemustaka. Menurut Peter Austin dalam penelitiannya seperti yang dikutip oleh Edward Sallis Gaya kepemimpinan yang dapat mengantarkan insitusi pada revolusi mutu disingkat MBWA atau management by walking about (manajemen dengan melaksanakan). Kepemimpinan MBWA seperti ini menekankan pentingnya kehadiran pemimpin dan pemahaman dan juga pendangan mereka terhadap staf perpustakaan.

c. Keterlibatan Personalia (SDM)

Manajemen yang baik adalah manajemen yang bertumpu pada sumber daya manusia. Sumber daya manusia dalam perpustakaan mempunyai peran penting dalam pencapaian tujuan. Hal ini karena dengan adanya keterlibatan sumber daya manusia akan mempengaruhi terhadap kinerja dan tingkat kemampuan staf di perpustakaan. Keterlibatan staf dalam manajemen di perpustakaan akan membawa dampak antara lain yaitu a. staf akan lebih termotivasi, berkomitmen dan terlibta dalam seluruh aktifitas di perpustakaan. b. staf akan merasa bertanggung jawab atas masalah yang ada di perpustakaan c. staf akan berbagi penhalaman dalam tim.

d. Pendekatan proses

Pendekatan proses adalah perpaduan dari orang, material, metode, mesin dan peralatan dalam suatu lingkungan guna menghasilkan nilai tambah keluaran (output) (BSN,2013). Pendekatan proses yang disampaikan oleh ISO 9001 merupakan proses aktifitas yang memanfaatkan sumberdaya untuk mentransformasi atau mengubah masukan (input) menjadi keluaran yang 
memiliki nilai tambah untuk pelanggan.

e. Pendekatan Sistem Terhadap Manajemen

ISO 9001 memberikan panduan untuk perencanaan, dan tujuan yang akan dibangun dengan pertimbangan kebutuhan pemustaka, sumber daya yang tersedia da kebijakan yang berlaku di organisasi. pendekatan yang dapat diterapkan antar lain : penataan sistem yang efektif dan efisien untuk mencapai tujuan perpustakaan, memahami saling ketergantungan setiap proses diperpustakaan, memahami salingketergantungan perpustakaan dan proses induk organisasinya, perencanaan, kegiatan dan kerja yang sistematis dan terkoordinasi, mengurangi hambatan lintas fungsional.

f. Perbaikan terus menerus

Peningkatan kinerja perpustakaan secara menyeluruh harus menjadi tujuan yang tetap. Untuk meningkatkan kinerja secara terus menerus maka diperlukan diteksi dan koreksi kesalahan sejak awal sehingga dapat dilakukan perbaikan secara terus menerus dalam setiap proses di perpustakaan. Prinsip perbaikan secara terus menerus bertujuan untuk : membuat perpustakaan lebih fleksibel untuk bereaksi cepa terhadap peluang, menyelaraskan strategi penignkatan kegiatan di perpustakaan, membuat perbaikan secara berkesinambungan terhadao proses dan jasa yag ditawarkan, menetapkan tujuan untuk melacak dan mengarahkan padaperbaikan berkelanjutan, memberikan alat untuk memotivasi dan menilai kinerja staf.

g. Pendekatan Fakta dalam Pengambilan Keputusan

Penerapan ISO 9001 memandu kita dalam pengambilankeputusanagarterusmenerusmeningkatkan proses, dan system mutu menawarkan informasi yang diperlukan. Pengambilan keputusan akan lebih efektif apabila keputusan yang diambil adalah keputusan yang didasarkan pada analisa data dan informasi untuk menghilangkan sehingga permasalahan dapat 
diselesaikan sampai akarnya. Dengan demikian dalam mengatasi suatu permasalahan diperlukan pencacatan data dan informasi untuk kepentingan analisa agar mutu data dan inforamsi yang dikumpulkan dapat dijamin.

h. Hubungan Yang Saling Menguntungkan dengan Pemasok

Dalam perpustakaan penerbit, toko buku, vendor mereka adalah pemasok produk yang ada di perpustakaan. Untuk menjaga hubungan mitra (bisnis) perpustakaan masing-masing pihak harus dapat menjalin hubungan yang saling menguntungkan. ${ }^{20}$

Dalam upaya penguatan mutu dan peningkatan pada sumber dayaguna untuk mencapai tujuan perpustakaan, peran pustakawan sangat menentukan bagaimana mutu yang dihasilkan dalam bisnis jasa informasi di perpustakaan meskipun ada factor lain yang juga berperan di dalamnya. Faktor sumber daya manusia di perpustakaan dalam hal ini adalah pustakawan sebagai pialang yang semestinya memegang kendali dalam menciptakan mutu layanan. Setelah implementasi manajemen mutu perpustakaan dapat dinilai sejauh mana kualitas yang diberikan kepada penggunanya. Penilaian atau akreditasi ini menjadi tolak ukur penilain dan pengakuan masyarakat. Pihak yang banyak berperan dalam proses akreditasi perpustakaan adalah pengelola perpustakaan khususnya pustakawan dan seluruh jajaran pegawai yang bekerja di perpustakaan. Pustakawan sebagai figur sentral harus mampu menciptakan perpustakaan yang sesuai dengan visi , misi dan tujuannya. Pustakawan dengan segenap kemampuan dan kompetisi yang dimiliki harus mampu menjadi manajer informasi dan siap dalam menghadapi perkembangan ilmu dan tuntutan masyarakat penggunanya.

\section{Peran Pustakawan dalam Akreditasi}

Penilaian kualitas atau mutu Dalam akreditasi perpustakaan perguruan tinggi meliputi beberapa instrument

ibid .hlm.14 .

r. 
yang harus disiapkan oleh pihak perpustakaan dalam hal ini adalah pustakawan dan segenap pegawai yang bertugas di perpustakaan perguruan tinggi. Mengenai persiapan dalam melakukan akreditasi perpustakaan Komarudin menyampaikan beberapa tahapan yang dilakukan untuk persiapan akreditasi perpustakaan yaitu :

a. Merencanakan Akreditasi.

Perncanaan semua kegiatan sangat penting dan mempengaruhi hasil akhirnya. Kegiatan perencanaan dalam kegiatan apa pun hendaknya harus dilakukan termasuk persiapan akreditasi perpustakaan. Waktu persiapan akreditasi setidaknya dilakukan setahun sebelum akreditasi dilaksanakan. Perencanaan kegiatan di perguruan tinggi semuanya tercantun dalam proposal kegiatan yang akan dilakukan.

b. Membentuk Tim Persiapan Akreditasi.

Pembentukan tim pelaksana harus ditentukan beserta pembagian tugas harus dibuat dengan matang agar semua anggota tim dapat bekerja dengan efektif dan efisien sesuai bidang tugasnya seperti bagian pengolahan, pelayanan, dan teknologi informasi. Semua anggota tim bertugas menyiapkan segala dokumen yang dibutuhkan dalam setiap tahapan akreditasi sesuai dengan ketentuan yang tercantum dalam pedoman dan borang akreditasi.

c. Melakukan self assessment

Proses selanjutnya adalah mempelajari borang akreditasi. Tim akredisasi yang diberi tugas mempersipakan dokumen-dokumen yang diperlukan untuk mendukung data berdasakan komponen yang ada dan sesuai dengan borang akreditasi.

d. Menyiapkan berkas data pendukung

Proses penyediaan dokumen dan data yang dilakukan oleh tim persipan akreditasi akan menjadi penguat dalam pengisian borang kareditasi. Dokumen disiapkan sesuai dengan daftar yang tersedia dalam 
borang. Dokumen secara utuh disiapkan di perpustakaan. Dokumen yang dikirim berupa dua format, fisik dan elektronik. Tidak semua dokumen secara utuh dikirim ke lembaga akreditasi tetapi hanya salinan yang menguatkan borang untuk mendukung terhadapa penilaian. Dokumen elektronik yang dikirim di jadikan dalam satu file atau beberapa file dalam folder dan dikelompokkan sesuai dengan kategori.

e. Mengirim surat dan berkas data pendukung

Borang akreditasi yang sudah diisi dan dilengkapi dengan data pendukung, langkah selanjutnya adalah mengirinkan surat permohonan akreditasi perpustakaan ke Perpustakaan Nasional selaku lembaga yang menilai. Selanjutnya lembaga akreditasi perpustakaan akan memberikan jawaban atas usulan akredtitasi yang diajukan.

f. Penilaian Borang

Penilaian borang dan dokumen yang diajukan oleh perpustakaan akan dinilai oleh tim akreditasi atau asesor selaku tim penilai. Setelah proses penilaian, selanjutnya akan disampaikan perihal kesiapan untuk visitasi. Apakah perpustakaan sudah siap menerima visitasi atau belum.

g. Menyiapkan visitasi

Tahapan berikutnya adalah persiapan visitasi . Mengenai pelaksanaan visitasi, lembaga akreditasi akan mengirim surat pemberitahuan beserta visitasi yang akan dilakukan. Pemberitahuan visitasi meliputi asesor yang akan menilai, waktu pelaksaan visitasi, dan tahapan apa saja yang akan dilakukan dalam proses visitasi. Pemberitahuan tentang persiapan yang harus dilakukan yaitu tahap presentasi, wawancara dengan staf, wawancara dengan pemustaka atau pengguna perpustakaan. Dalam presentasi juga harus dilengkapi data pendukung seperti foto kegiatan, hasil karya perpustakaan baik jurnal maupun karya yang lainnya. 
h. Menghadapai visitasi.

Dalam rangka penyambutan kedatangan tim asesor, tim persiapan akreditasi perlu mempersiapkan akomodasi kegiatan visitasi dengan sebaik-baiknya supaya kegiatan akreditasi berjalan dengan lancar. Berikut ini kegiatan yang dilakukan dalam proses visitasi yaitu :

1. Presentasi

2. Wawancara

3. Kunjungan lapangan dan wawancara dengan pemustaka

4. Pengumuman atau pembacaan hasil penilaian secara umum dan rekomendasi. ${ }^{21}$

Menurut Pedoman akreditasi perpustakaan Perguruan Tinggi yang dikeluarkan oleh Perpustakaan Nasional tahun 2013 seperti yang dikutip oleh Sulistyo Basuki ada beberapa instrument yang harus disiapkan oleh pustakawan dalam penilaian perpustakaan Perguruan Tinggi seperti yang tercantum dalam tabel sebagai berikut ini adalah

Tabel. 2. Komponen dan Bobot indikator versi Perpusnas

\begin{tabular}{|c|c|c|c|c|}
\hline No. & Urutan komponen & $\begin{array}{c}\text { Jumlah } \\
\text { indikator } \\
\text { kunci }\end{array}$ & $\begin{array}{c}\text { Bobot tiap } \\
\text { indikator } \\
\text { kunci }\end{array}$ & $\begin{array}{c}\text { Skor } \\
\text { minimal }\end{array}$ \\
\hline 1. & Layanan dan kerjasama & 10 & 3 & 30 \\
\hline 2. & Sumber Daya Manusia & 13 & 2 & 26 \\
\hline 3. & Koleksi & 12 & 2 & 24 \\
\hline 4. & Sarana \& Prasarana & 19 & 1 & 19 \\
\hline 5. & Sumber Daya Elektronik & 10 & 1.5 & 15 \\
\hline 6. & $\begin{array}{l}\text { Gedung dan ruang } \\
\text { perpustakaan }\end{array}$ & 12 & 1 & 12 \\
\hline 7. & Anggaran & 5 & 2 & 10 \\
\hline 8. & Pengolahan Bahan & 5 & 2 & 10 \\
\hline 9. & Organisasi Perpustakaan & 4 & 1.5 & 6 \\
\hline
\end{tabular}

Sumber: Sulistyo Basuki."Akreditasi perpustakaan perguruan tinggi". (Akreditasi, 2010)

${ }^{21}$ Komarudin, 'Menyiapkan Akreditasi Perpustakaan".Library. stainkediri.ac.id/menyiapkan-akreditasi-perpustakaan/ 
Komponen dan indikator serta bobot nilai yang ditentukan dapat menjadi dasar bagi perpustakaan untuk lebih fokus dalam mempersiapkan komponen apa saja yang akan dinilai, sehingga sebelum proses akreditasi tim persiapan yang ditugaskan akan lebih optimal dalam menjalankan tugasnya menyiapkan segala keperluan dokumen serta data pendukung yang sesuai dengan borang akreditasi.

Berikut ini komponen-komponen yang harus disiapkan oleh pustakawan beserta seluruh staf yang bertugas di perpustakaan setelah mempelajari dan memahami borang akreditasi yaitu :

a. Layanan dan Kerjasama.

Aspek layanan perpustakaan meliputi jam buka layanan yang di perhitungkan dalam jadwal dan harus memenuhi jam buka layanan bagi pemustaka dalam harian dan mingguan, system peminjaman yang diberlakukan, prosentasi keanggotaan dosen, mahasiswa dan tenaga kependidikan, frekuensi peminjaman dari anggota buku/bulan, promosi perpustakaan (berapa kali dan apa bentuknya), layanan berbasis TIK, literasi yang dilakukan. Begitu juga untuk aspek kerjasama untuk pengembangan perpustakaan yaitu kerjasama bidang layanan dan peminjaman dengan perguruan tinggi lain.

b. Sumber Daya Manusia.

Aspek Sumber daya manusia yang harus dipersiapkan meliputi status tenaga perpustakaan (kepala perpustakaan, pustakawan, tenaga teknis, dan tenaga fungsional lain seperti arsiparis dan pranata komputer), Jenjang pendidikan formal tenaga perpustakaan, Diklat tenaga perpustakaan yang diikuti, Kegiatan pengembangan program perpustakaan yang dilakukan tenaga perpustakaan, Pembinaan tenaga perpustakaan.

c. Koleksi.

Aspek koleksi meliputi jumlah koleksi cetak secara keseluruhan, prosentasi koleksi yang menunjang kurikulum program studi, koleksi referens yang dimiliki, 
surat kabar yang dilanggan, jurnal yang dilanggan dengan perbandingan program studi, koleksi khusus seperti skripsi, tesis, disertasi, dan hasil penelitian, penambahan koleksi yang terbanyak dalam setahun, stok opname, penyiangan, survey kebutuhan koleksi, sumber daya elektronik (monograf), jurnal elektronik yang dilanggan, website/homepage perpustakaan, system otomasi yang diterapkan.

d. Sarana dan Prasarana

Aspek sarana dan prasarana meliputi luas bangunan atau gedung perpustakaan, pembagian area untuk masing-masing jenis koleksi, pemustaka, staf dan area lain seperti lobi, ruang tamu dan toilet, kebersihan seluruh bangunan dan are perpustakaan, penerangan yang dipakai, sirkulasi udara, letak/lokasi perpustakaan, keamanan yang diterapkan, rak buku yang dimiliki, rak jurnal, rak surat kabar, rak multimedia, rak buku referens, laci catalog jika ada, rak display buku baru, lemari penitipan tas pengunjung, fillinf cabinet, papan pengumuman, meje belajar perorangan, meja baca, meja sirkulasi, meja petugas, kursi baca, kursi tamu, computer dan printer untuk kegiatan perpustakaan, scanner, computer pemustaka untuk layanan internet, perangkat multimedia (VCD/DVD Player, kaset recorder), TV, kipas angin, AC.

e. Sumber daya Elektronik meliputi

Aspek Sumber Daya Elektronik meliputi e-book yang dimiliki, e-journal yang dilanggan dan bisa diakses pemustaka, website yang dikelola, system otomasi perpustakaan yang dipasang.

f. Gedung dan Ruangan

Aspek gedung dan ruangan meliputi letak/lokasi perpustakaan, pembagian ruangan perpustakaan untuk semua area koleksi, staf dan pemustaka, dan perawatan gedung. 
g. Anggaran

Aspek anggaran meliputi sumber pendanaan/ anggaran, jumlah anggaran yang diperoleh, alokasi penggunaan anggaran, pemanfaatan dana

h. Pengolahan Bahan

Aspek pengolahan bahan meliputi penggunaan alat seleksi bahan perpustakaan (bibliografi, anotasi, timbangan buku), pengolahan monograf meliputi registrasi/pencatatan, klasifikasi, penetapan subjek, deskripsi bibliografi, penggunaan label, pengolahan majalah baru, system temu kembali informasi, kelengkapan buku (slip tanggal kembali, kantong buku, kartu buku, label buku, barcode/chip)

i. Organisasi Perpustakaan

Aspek organisasi perpustakaan meliputi kelembagaan perpustakaan, struktur organisasi, kepala perpustakaan, sejarah pendirian perpustakaan, program kerja perpustakaan, laporan kegiatan yang disusun.

Demikian komponen-komponen beserta dokumen dan data yang harus dipersiapkan oleh tim persiapan akreditasi untuk persiapan akreditasi perpustakaan dalam rangka peningkatan mutu pendidikan perguruan tinggi. ${ }^{22}$

\section{Simpulan}

Perpustakaan sebagai unsur pendukung dalam pendidikan tinggi memegang peranan penting dalam penyebaran keilmuan. Dalam pelaksanaan tugasnya perpustakaan harus dapat menunjukkan kualitas atau mutu baik dalam sumber daya manusianya maupun koleksi yang dimiliki. Untuk mendukung program peningkatan mutu perpustakaan semua jajaran dan pegawai perpustakaan harus berperan aktif dalam menjalankan kegiatan sesuai tugas yang diberikan. Dalam rangka peningkatan

22 Perpustakaan Nasional RI.Akreditasi Perpustakaan Perguruan Tinggi, Jakarta : Pusat Pengembangan Dan Pengkajian Minat Baca , 2013 
mutu perpustakaan, pustakawan beserta seluruh staf yang bertugas di perpustakaan harus bekerjasama berusaha mempersiapkan segala keperluan dokemun dan data untuk seluruh komponen yang akan dinilai oleh tim akreditasi untuk untuk keperluan penilaian demi terciptanya mutu pendidikan di perguruan tinggi. 


\section{DAFTAR PUSTAKA}

Abbas, Syahrizal. Manajemen Perguruan Tinggi: beberapa catatan, Jakarta: Kencana Media, 2009

Alma, Buchari. Manajemen corporate \& Strategi Pemasaran Jasa Pendidikan, Bandung: Alfabeta, 2009

Edward, Sallis. Manajemen Mutu Terpadu Pendidikan, Jogjakarta: IRCiSoD, 2011

Hedwig, Rinda \& Geradus. Pola Model Sistem Penjaminan Mutu \& Proses Penerapannya di Perguruan Tinggi, Yogyakarta: Graha Ilmu, 2006

Hardiningtyas,Tri. Pustakawan \& Angka Kreditnya, Yogyakarta: Lembaga Ladang Kata, 2015

Kamus Besar Bahasa Indonesia: Edisi Ketiga, Jakarta: Balai Pustaka, 2007

Komarudin."Menyiapkan Akreditasi Perpustakaan."Librarystainkediri.ac.id/menyiapkan-akreditasi-perpustakaan/ (diakses tanggal 10 September 2016)

Perpustakaan Nasional. Akreditasi Perpustakaan: Perpustakaan Nasional, Jakarta : Perpusnas, 2013

Peraturan Pemerintah Nomor 24 Tahun 2014

Peraturan Pemerintah RI Nomor 50 Tahun 2014

Peraturan Kepala Perpustakaan Nasional RI Nomor 2 Tahun 2008

Peraturan Kepala Perpustakaan Nasional RI Nomor 11 Tahum 2015

Sumardjoko,Bambang. Membangun Budaya Pendidikan Mutu Perguruan Tinggi: Analisis Perguruan Tinggi Swasta di Surakarta, Jakarta: Pustaka Pelajar, 2010

Syihabuddin,Qalyubi. Dasar-dasar Ilmu Perpustakaan Dan Informasi, Yogyakarta: Jurusan Ilmu Perpustakaan Dan Informasi, 2003

Sulistyo, Basuki. Akreditasi Perpustakaan Perguruan Tinggi, http:// sulistyobasuki.wordpress.com/2013/10/27/akreditasi- 
perpustakaan-perguruan tinggi/( diakses tanggal 3 september 2016 )

Undang-Undang Nomor 43 tahun 2007 Tentang Perpustakaan

Undang-Undang Nomor 20 Tahun 2003 Tentang Sisdiknas \& Undang-Undang Nomor 14 Tahun 2005 Tentang Guru dan Dosen.Dilengkapi Peraturan Pemerintah Nomor 19 Tahun 2005 tentang Standar Nasional Pendidikan. 